RESEARCH ARTICLE

\title{
The View from the Traveller Site: Post-nomadic Subjects and the Material Relations of Permanent Temporary Dwelling
}

\author{
Anna E. Hoare*
}

The Caravan Sites Act 1968 imposed a duty on local authorities in the United Kingdom to provide sites for 'gipsies' (sic). Contradictory aims of active repression, enforced dependency and notional integration combined in a mode of dwelling invented and controlled by the state, but increasingly promoted, transformed and privatised by Travellers themselves. In a ruling in 2004 against the United Kingdom, the European Court of Human Rights found that local authority sites were 'homes' under Article Eight of the European Convention on Human Rights, and tantalisingly described the UK's Traveller population as 'nomadic in spirit if not in actual or constant practice' (Connors v. the United Kingdom, ECtHR 267, 2004, Press Release of the Registrar: 4). This paper explores the paradox of permanent temporariness imbedded in the relation between the UK Traveller site, the legal category of the gypsy, and the house of the post-war planning system. It argues that post-nomadic architectures and subjectivities radically challenge the publicprivate nexus of citizenship, property, and family objectified in the post-war ideal of the permanent house. In the house, as Engels (1948 [1891]) describes, political economy and the materiality of dwelling and family life collide, and the tension of contradictions eventually gives rise to new house forms and concomitant social relations. The paper draws on anthropological fieldwork in the UK and Ireland to revisit the house as a field of productive instability.

\section{Introduction}

I shall begin by clarifying the concept of post-nomadism, used here with reference to the subject and to architecture. Rather than supposing a transition between forms of life conceived as distinct and whole, one nomadic and the other sedentary, post-nomadism suggests transformations of a nomadic way of life without assuming that they constitute a

\footnotetext{
* Department of Anthropology, UCL,

United Kingdom

a.hoare@ucl.ac.uk
}

trajectory toward a sedentist notion of becoming settled. These transformations, which are variously legal, material, political and social, cannot in practice be disentangled. Familism, architecture and settlement form, and the status and claims of legal/extra-legal subjects are interdependently involved.

We may not assume such changes will result in either greater incorporation or increased alienation vis à vis the state. As described in the European Court's press release following Connors $v$ The United Kingdom in 2004 (ECtHR Application no. 


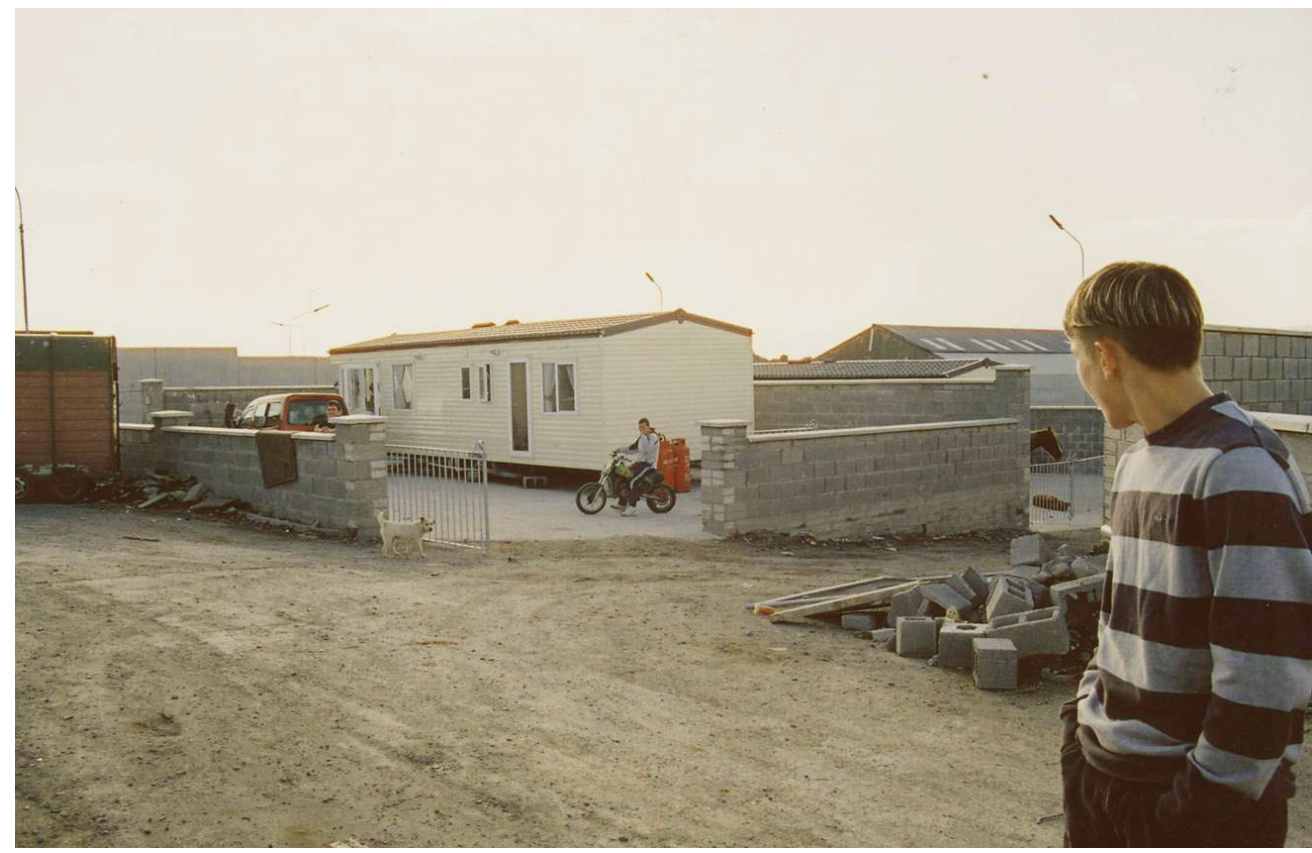

Fig 1: View from the Traveller site. Site reconstruction. Ireland 2007.

66746/01), contradictory processes occur in tandem, irresolution and legal insecurity persist, and state policies turn out to have unexpected consequences. In the UK as elsewhere, the homogenising tendency of the state is belied by forms of governance that depend upon 'culturalist rhetorics' of incommensurability (Stolcke 1995: 4), reproducing hierarchies of citizenship as irreducible facts. Ambiguous citizenship, such as the category of the gypsy in UK planning law, constitutes an enduring element of the Foucaultian play of forces that constitute modern states (Agamben 2005; Feldman 2001; Neumann 1996; Yiftachel 2009).

Post-nomadic architecture and, in particular, the Traveller site (Figure 1), the focus of this paper, is thus the material centre of unresolved questions about the role of law and the state in dwelling, property and familism. Drawing on Judith Butler's rejection, in Antigone's Claim (2000), of the notion that kinship constitutes a pre-political sphere, we might frame the question: When the state confronts intimate sites of human embodiment and reproduction, turning them into representations and instruments of power, what kind of deformation of sovereignty occurs? This paper explores the relation between the officialised material world of the Traveller site, the symbolic deformation of the post-war house, and the configuration of post-nomadic subjectivities.

Among post-nomadic subjects, family formation, livelihoods, architectures, and modes of dwelling are shaped and reworked at intersections (points of conflict or accommodation) between notions of authority, concepts of personhood, parallel as well as integrated economies, and, increasingly, both national and transnational systems of law. Butler states that Antigone's 'autonomy is gained through the appropriation of the authoritative voice of the one she resists' (Butler 2000: 11). Such a conflict between 'simultaneous refusal and assimilation of [resisted] authority' (Butler 2000: 11) determines the predicament of post-nomadic subjects, who seek, by turns, to circumvent, deploy, and challenge national laws which were designed to relieve 
the state of the burden of 'requisite procedural safeguards' (ECtHR Registrar 2004: 4) in its dealings with Travellers. Post-nomadic subjectivities thus pose what Balibar calls the onto-political problem of the subject. He observes: '[T]he modern identity of man and citizen did not lead to the pure and simple negation or Aufhebung ${ }^{1}$ of the subjection to the Law, as an "inner" voice. It has led, rather, to a new twist, a new degree of interiorisation ... along with a new "privacy" of the moral sentiments' (Balibar 1994: 13). This new interiority is made visible as the 'collective or transindividual construction of ... individual autonomy' (Balibar 1994: 12). Following Balibar, subjectivity, as the term is used here, thus speaks of a public (or collective) self-relation that claims for "private life $^{2}$ the right to self-determination (Warner 2002). For contemporary Travellers in the UK and Ireland, self-determination is expressed as a cultural claim to the 'private life' of the Traveller site, and this claim, including the limitations on state interference to which it gives rise to under Article Eight of the European Convention on Human Rights (ECHR), was upheld by the European Court's 2004 judgment in the case of Connors.

In this context, the paper explores the status and materiality of the UK Traveller site as part of a field of dwelling and private life normatively constituted by the house of the post-war planning system, and considers the transformations, challenges, and subjectivities that animate this field. The planning system, understood less, in its own benign terms, as a rational system for organizing the built and natural environment, is perceived as a form of government in which interdependent oppositions between notions of public and private are extensively redefined in and through property. In other words, the house of post-war planning, frequently referred to here as a field, is the institutional and material form of unresolved social relations between subjects and the state.

This paper is divided into two main parts, followed by a concluding discussion that questions the concept of the field as conceived by Bourdieu (1985, 1989), and its dialectical configuration with the habitus of subjectivity. The first section traces the ideological origins of the Traveller site in government's attempt to rationalise an unkempt edge of dwelling without property that eluded the post-war system of planning. This examines the history of a key opposition between values of permanence and temporariness that continues to contour mutual resistance between the site and the house.

The second part, drawn from fieldwork carried out in the UK between 2005 and 2007, describes a raid on a site by police and planning officers, and looks at how contemporary relations between the site, the house, and the legal category of the gypsy are played out in practice.

The final discussion considers Bourdieu's endeavour to reconfigure the problem of the subject $(1977,1985)$ in the idealised dialectic between habitus and field. The paper concludes that ethical relations between architecture, dwelling and politics, where the field of the house is neither autonomous nor bounded, demand a more nuanced account of the politics of gesture in post-nomadic subjectivities.

\section{A note on orthography and terminology}

The terms 'gypsy' and 'Gypsy' are used throughout this paper in their legal and technical meanings. In planning law, the uncapitalised 'gypsy' refers to 'persons of nomadic habit of life, whatever their race or origin' (Caravan Sites and Control of Development Act (CSCDA) 1960 s24 (8)). Travellers who have lived in houses are sometimes claimed to have lost their 'gypsy status' (Johnson and Willers 2007: 109-115), a charge which prejudices a planning application for a private site; gypsy status, a legal concept that plays an important role in the self-determination of Travellers' modes of dwelling, is thus a principal area of legal contention. The upper 
case form, 'Gypsy,' as used in race relations, conveys the law's concept of membership of an ethnic group, and makes anti-Gypsy discrimination illegal. $^{3}$ Government publications characteristically observe the legal implications of these different spellings, often using both forms in the same document, ${ }^{4}$ since, in law, someone can be a gypsy without being a Gypsy, and vice versa.

However, the upper case form is often used exclusively by contemporary advocates of Gypsy rights, including lawyers, activists and many scholars, irrespective of context. Although scholars and activists seldom explain such orthographic decisions, it could be inferred that this normative delineation of (legal) ethnicity is held to reflect a more complete idea of the natural or social person. In the case of Johnson and Willers' legal handbook (2007) the use throughout of 'Gypsy' for planning law's 'gypsy,' on the basis that only the former spelling is correct (personal communication with Chris Johnson), implies that legal and natural persons are one and the same, and leads to confusing results in discussions of national law. To add to this complexity, in contrast to both the UK government and Gypsy advocates, the European Court of Human Rights (ECtHR) uses only the lower case form, 'gypsy', to refer to natural persons. In other words, ECtHR does not distinguish legal from natural (human) persons, with the exception of the state (a legal person only), and human rights are held to be natural rights.

It should be acknowledged that orthographic practice is not fixed, and continues to change in relation to Travellers' legal and political status. Notably, a Communities and Local Government publication in 2008, 'Implementing the Mobile Homes Act 1983 on local authority Gypsy and Traveller sites,' uses the upper case spellings of Gypsy and Traveller throughout, although the subject is planning law. (This example, to my knowledge, is exceptional.)

This paper reflects a critique of essentialist or official notions of natural persons, based on the understanding that both technical 'gypsies' and 'Gypsies' qua natural or 'ethnic' persons denote politico-legal categories. I aim to show how such categories are performatively realised in the discursive and material architectures of the Traveller site and the courtroom. I use the legally undefined term 'Traveller', long used by English Romany, Scottish, and Irish Travellers, except where a specific politico-legal meaning of 'Gypsy' or 'gypsy' is intended. The upper case reflects widespread current usage: it distinguishes Travellers from the general term, travellers, and reflects Travellers' recognition of shared, nomadic histories and ethnic relations with sedentary society.

\section{The invention of the Traveller site}

The aim of the Caravan Sites Act 1968 Part II (CSA) was to license and control a mode of dwelling that would mediate a transition in which nomadic subjects could be encouraged to adopt 'a settled way of life' without actively 'assimilationist' policies (cf Adams et al 1975: 11-12, 20-21). Local authorities, having failed to respond to the earlier Caravan Sites and Control of Development Act 1960 (CSCDA), which empowered them to provide sites, would now be compelled to do so.

Importantly, it was not only the way of life of those termed gypsies which the 1960 Act had targeted, but a diverse, growing population. A government-commissioned report in 1959 entitled Caravans as Homes (Wilson 1959), estimated that, 'vagrants apart,' one in three hundred of the population was living permanently in a caravan (Mann 1961: 151). This amounted to around 60,000 households or 150,000 people, excluding those Wilson identified as 'gypsies and vagrants' (HL Deb (1960), 244: Col. 581). An industry that produced 1,000 caravans per year in 1938 was turning out 86,500 twenty years later (Jackson 1965: 216-7). However, in the years leading up to the two Caravan Sites Acts, which in the first instance sought to control caravan-dwelling tout court, perceptions of a 
'gypsy problem' (Dodds 1966: 26, 160) distinguished between different types of 'caravanners,' and this distinction soon held legal consequences.

First, the 1960 Act imposed a licensing requirement on all land occupied by caravans. This led to widespread evictions of encampments of perceived gypsies (Adams et al 1975: 11-13). Farmers and landowners who had allowed seasonal workers to overwinter caravans on their land opted to turn them off rather than establish formal, licensed sites (Dodds 1966: 151; Kenrick and Clark 1999: 88). Since local councils now managed the commons as public space, the CSCDA1960 granted them the power to evict caravans from commons and woodlands which had long supported nomadic populations. The combined impact of these provisions was dramatic. Long lines of caravans began to appear alongside the A2 and other major roads (Evans 2004: 98-99). While councils embraced the new sanctions against Travellers, the power to provide legal sites was ignored.

In the face of growing pressure, the Caravan Sites Act 1968 imposed a duty on local authorities to provide sites 'for the use of gipsies [sic] and other persons of nomadic habit' (CSA 1968: 1), which from the first were thus known as gypsy or Traveller sites. The status and tenure of local authority site residents marked them out from occupants of licensed, private caravan sites. Protection from arbitrary eviction, introduced in 1968 for 'residential occupiers' of private sites, did not apply to local authority gypsy sites (CSA 1968: 1-2). Licensed residential sites were called 'protected sites' and their different legal status was further enhanced by the Mobile Homes Act (MHA) 1983, which increased residents' security of tenure (Johnson and Willers 2007: 65-66). To sum up, from the outset a tension existed in caravan site policy and legislation between improving living conditions and security for those who were not defined as nomadic by controlling the abuses of hitherto unlicensed landlords, and, depending on one's point of view, either controlling, attempting to eliminate, or facilitating the way of life of habitual nomads or gypsies, perceived (as official orthography would later reflect,) although not acknowledged, as a kind of people, 'Gypsies' (cf Dodds 1966: 17-19; Veysey-Fitzgerald 1944).

In the view of some advocates, local authority sites were a way of encouraging settled or 'integrated' life (Dodds 1966: 25), which meant fixed employment and school education for children. Some, including MP Norman Dodds, sought to end the criminalisation of Travellers that resulted from the CSCDA 1960, while broadly supporting policies that would eventually 'eliminate the gypsy problem' (Dodds 1966: 25), understood fundamentally as a humanitarian issue. For an alliance that included the Gypsy Council and the National Council for Civil Liberties (NCCL), sites meant recognition of Travellers' right 'to participate in our multi-racial society as a minority group with a distinctive culture and style of living' (cited in Adams et al 1975: 14). The enormous variation or incompatibility between the viewpoints of different advocates of statutory local authority Traveller sites meant that the 1968 Act was widely welcomed and encountered little opposition, although what sites really were and what they would do was far less clear.

\section{Formalising the temporary}

The salient notion of gypsy dwelling as temporary underwrote local authority site policy. In the first instance, it suggested an external perspective of nomadic dwelling as 'here today and gone tomorrow,' or temporary-initself. Second, the caravan, defined by size, mobility, and construction (CSA 1968: 6-7), signalled material grounds of difference from the supposedly permanent house. And third, as explored below, it harboured an expectation of policy-makers that legislative pressure would curb, if not rapidly eliminate, mobile or temporary dwelling. Between these temporal, material, and politico-historical implications of the temporary, the gypsy caravan 
might be perceived as something which has no automatic right to remain, which is which is tolerated for the time being, and, unlike a house, can legitimately be got rid of. The denial to local authority site gypsies (as defined by CSA 1968) of rights and security comparable to those of the residents of park homes, as they came to be known, reinforces this interpretation.

Precedents for dealing with the temporary could be found in Abercrombie's 1944 Greater London Plan, the blueprint of the post-war planning system. A key proposal here was to empower local authorities to license existing private dwellings on owneroccupied land that were nevertheless perceived as unacceptably 'temporary' on an annual basis, under a system of 'proper surveillance' (Abercrombie 1945: 131-132), and with a background threat of compulsory purchase. Having effectively curtailed the interwar growth of plotland settlements on low-value agricultural land through the new mechanisms of land zoning and the greenbelt, the aim of licensing private property was to ensure that the jumble of shacks and bungalows on the Laindon Hills and at Pitsea' and elsewhere would transform into 'permanent' houses under the watchful eye of the state (Abercrombie 1945: 98).

In short, property was incompatible with temporariness. The enormous expansion of land ownership that, for the small price of a rural plot and a caravan or self-built 'shack' bought freedom from urban landlords and the ruin of war, was to be halted by the state's new tenure of the real house, defined as 'permanent' and controlled by planning. If, as seems inevitable, the Caravan Sites Acts of 1960 and 1968 were influenced by the Greater London Plan's values and assumptions, a crucial distinction-that the Traveller site would officialise intentional temporariness-was overlooked.

The contradictions between enforced dependency, active repression, and notional integration that the 1968 Caravan Sites Act embodied marked the paradox of the official
Traveller site's formal delineation of an informal status, that of the nomadic 'gypsy' indicated by the Act (discussed below). Traveller dwelling in this guise would neither be incorporated on an equal footing by the planning system nor utterly excluded. The site was neither a camp nor a house, and lacked the principal features of either. We might briefly characterise these here.

Irish Travellers concisely describe the camp's recursive settlement form, based on variation and repetition, as 'coming and going.' This phrase distinguishes the sociality of dwelling in camps from the contingent mobility of nomadic subsistence, referred to simply as being 'on' or 'beside the road.' Camps foreground enduring interdependencies between ever-extending transformations of adjacent generations of one's 'own people.' These interests and commitments are made visible by 'coming and going' between multiple camps of the 'own people' of both husband and wife, to whom unmarried offspring belong equally. The site's physical boundaries, designed to contain a fixed coalition of rent-paying gypsies and to prevent the flexibility of the camp, definitively preclude the intentional architectures of 'coming and going' (see also Kenrick and Clark 1999: 95-100).

The distance between the site and the house was similarly unbridgeable. In 1944, the house had been newly re-imagined at the centre of planning's system of government. The state authorised private property (land and buildings) subject to the claim of state ownership over the use of property. From 1965, statutory building standards constituted a built-in modality of government. ${ }^{5}$ The dimensions of windows, footings, joists and plumbing pipes, the angle of stairs, and construction of roofs all stamped the house as a fully legal commodity-a real, that is to say, permanent house. The dependent status of the site in local authority ownership and the statutory materiality of temporary dwelling strategically prevented the Traveller site from becoming property, while Travellers 
themselves shared neither the legal protections of householders nor those of the residents of protected sites.

\section{House/ home/ property}

The bricks and mortar house thus materialised interdependency and opposition between notions of public and private in a configuration that has come to dominate the interproduction of familism, property, and citizenship. A semi-autonomous agent of Abercrombie's vision of the 'balanced arrangement' of ideal community, in which neighbourhoods and towns enjoy 'physical definition and unmistakeable separateness' (Abercrombie 1944: 112), the house, its value under-written by the state, was the officialising structure (Bourdieu 1990: 108) of the field of dwelling ${ }^{6}$ tout court, the authorised manifestation of stable, social relations and imaginary scene of personal autonomy. Three overlapping terms, which can never be utterly disentangled-house, home, and propertydelineate commodified and decommodified value in the same object, marking insecure separations between autonomy, dependency and resistance in the public-private relations of the house.

The state's new tenure of the house had distinct advantages for those who owned land and buildings in 1945. By limiting the supply of building land, land zoning instantly increased the commodity value of houses, while, from 1965, statutory building standards fetishised a technical system of autonomous value in the house. Real, permanent houses could be imagined as almost limitless instruments of production, constantly producing value, provided that the state, as the surrogate of Abercrombie's 'community' (Abercrombie 1945: 112-116), maintained its 'proper surveillance' (Abercrombie 1945: 132) over what went on beyond the fence. This new configuration of value and interest was now intensely predicated on the outside of the house in ways that made it vulnerable.

From the late twentieth century, as Travellers have begun to seek planning permission for privately-owned sites, the mythic crime of the gypsy has become the theft of value from the house. ${ }^{7}$

\section{The gypsy as legal person}

The first definition of the gypsy in law, that of Mills v Cooper 1967 (All E.R. 100, 1967), arose in response to a challenge to prosecution. The 1959 Highways Act (S. 127) made it illegal for a 'gypsy' to park overnight beside the road, an act that was lawful for persons of any other status. ${ }^{8} \mathrm{Mr}$ Cooper's defence was that he was not a gypsy, an argument that had proved successful for him once before. For centuries until Mills $v$ Cooper penal law had found it unnecessary, and certainly not useful, to engage in the matter of definitions, preferring to use a scattergun of vague terms - 'gypsies,' 'vagrants,' 'vagabonds,' and 'masterless men' (cf. Fraser 1993, Mayall 1988, Willems 1998) - to round up those the state sought to condemn. 'Gypsies' were thus 'our Middle Ages preserved; dangerous classes of an earlier epoch' (Becker-Ho cited in Agamben 2000: 64).

What gave rise to the judges' definition of the 'gypsy' as a 'nomad' in Mills $v$ Cooper was the move from a property regime that included commons to one of interdependence between material notions of public and private. As well as highways, public space included woods and commons that fringed the metropolis, the green lungs of Abercrombie's urban body, and suddenly, there was an urgent relation between the two. Those evicted from the commons who were now forced to camp beside the road were the specific targets of the 1959 Highways Act: gypsies, albeit still undefined in law. The category of the gypsy thus objectifies a particular relation, one of intrinsic illegality, to this spatialised public realm where the state's intention is made visible, that of the former commons. In spite of Lord Parker's caution that his definition of "'gypsy" [meaning] no more than a person leading a nomadic life with no, or no fixed, employment and with no fixed abode ... will 


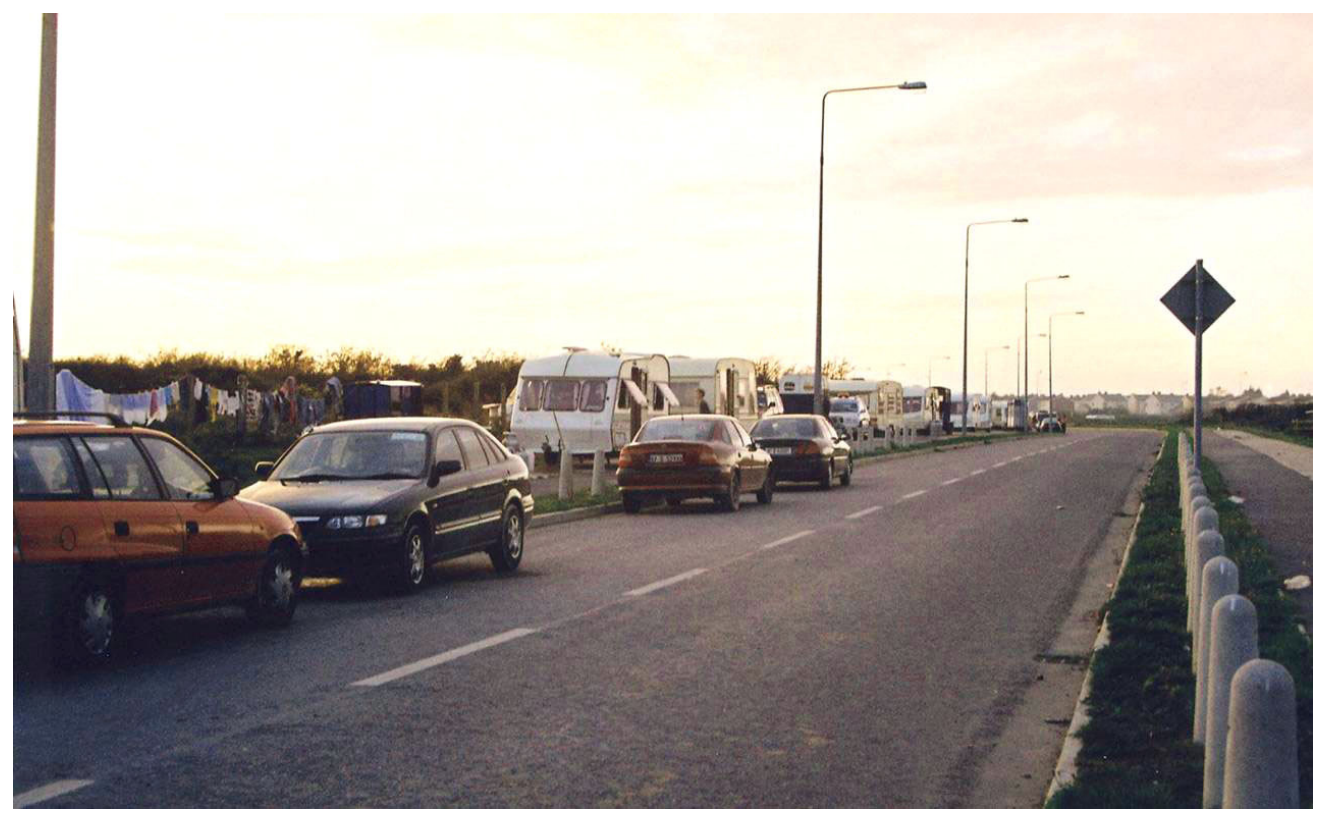

Fig 2: Roadside camp. Ireland 2007.

not be considered as the words of a statute' (All E.R.100 at 103H, cited in Sandland 1996: 388), this new legal person, whom Lord Parker CJ confirmed 'merely as conveying the general idea of a gypsy' was about to be made visible in the 1968 Caravan Sites Act by means of a register of effects negatively determined by property and the real, permanent house.

$\mathrm{Mr}$ Cooper, being a gypsy according to 'the general idea of a gypsy' (All E.R.100 at $103 \mathrm{H}$, cited in Sandland 1996: 388), was convicted. The anti-gypsy provisions of the 1959 Highways Act were subsequently transferred to the 1968 Caravan Sites Act, on the basis that the precedent of colloquial usage established in Mills could escape challenge under the new race relations law of the same year. The topology of public space / permanent house / temporary site / illegal gypsy beside the road, left, to use Foucault's phrase, 'no spaces of primal liberty between the meshes of its network' (Foucault 1980: 142). The state's acknowledged legal obligation to 'facilitate the Gypsy way of life' ${ }^{9}$ meant, in practice, that $\mathrm{g} /$ Gypsies were confined to official sites, and that going on the road with a caravan or trailer effectively placed the $\mathrm{g} /$ Gypsy outside the law.

To examine the specific logic of official Traveller dwelling that emerged in the years following the 1968 Caravan Sites Act, I turn next to the account of a raid on a local authority Traveller site (Figure 2).

\section{The raid ${ }^{10}$}

In 2005, police and council officials carried out a raid on a local authority owned site that had been occupied for around fifteen years by an extended family of Irish Travellers. They inspected sheds, trailers, and chalets; demanded to see numerous official documents, ranging from TV licences to motor insurance certificates; and ordered residents to pull down dog kennels in their yards. Finally, the officials stood in front of one of the dwellings that Travellers picturesquely call chalets, with perplexed expressions.

Chalets are large, so-called static mobile homes, which are delivered to the site by low-loader and then rolled into position on 
tiny wheels. Two can be joined together to make a five or six room dwelling that conforms to the 1968 definition of a mobile dwelling, though it scarcely resembles a caravan. Sometimes, chalets and caravans are dispersed around a yard and one is used as a kitchen and day-room, another as a parlour and bedrooms, and so forth. Once a chalet is in position, piers of concrete blocks are placed at each corner to level and stabilise it, and a skirting wall of blockwork is often constructed all round the base of the caravan to keep out drafts, damp, or animals. In keeping with the chalet, this skirting wall is frequently painted white. This was what had been done here.

Pointing at the ground beneath the wall an official asked, 'Is there a concrete footing under there?' The Travellers assured him there was not. Then, looking at the wall itself he demanded, 'Is there any mortar between those blocks?' The Travellers insisted there was no mortar, then to underline the point the men declared with bravado, "We can have the whole lot moved out in two hours!' Everyone looked apprehensively at what resembled nothing less than a house, which had stood there for over ten years, with mains wiring, plumbing, and drainage. It was a tense moment, but the officials did not seek to have this verbal demonstration literally enacted.

While recounting this story, punctuated by the alarm, humiliation, and humour the raid evoked, the Travellers explained: 'We are not allowed to do anything that goes below the surface of the ground.' No matter how long the group occupies the site, in fact, even if they owned it, the site embodies a form of temporary dwelling whose materiality hinges on the gypsy defined in law as a nomad. Any sign of permanence would render the Traveller site meaningless, or chaotic. However, as in this case, the hypothetical mobility of Traveller dwelling is tested not by actual movement, but by demonstrations of its ability to be got rid of, which define its unlikeness to the real house.

\section{The site as a parallax}

It is important to note that the site's architectural intentionality or status as a gypsy site is signified by the absence of something, moreover, an absence that cannot be observed. The closer the inspectors get to the material site, the more the numinous substance of gypsy dwelling recedes from view. This real invisibility is affirmed by the Travellers qua gypsies, who know the rules of the game. They offer assurances that they can see the site in its all, both visible and invisible, and, by way of proof, they even offer to make it disappear completely. The constitutive gypsyness of the site, which is both more and less than its materiality, occupies a gap 'beyond the opposition of the phenomenal and the noumenal' (Žižek 2006: 23), and in this gap (first person) Travellers appear as official (third person) gypsies.

This can be understood as the phenomenon of the parallax, which Žižek uses to explore Kant's category of the transcendental (Žižek 2006: 20-28). The philosophical problem of the parallax is not simply that the same object perceived from two different positions leaves something unseen ${ }^{11}$ that would make it really whole-the Ding an sich or noumenal Thing-in-itself (Žižek 2006: 27)-but that seeing incorporates the incommensurability of perspective in the seen-object, something 'in it more than itself' (Žižek 2006: 18). Another way of describing the parallax, Žižek writes, is as a 'minimal difference which divides one and the same object from itself,' and is 'itself an object' (Žižek 2006: 18). In the raid, the incommensurable perspectives are those of officials looking for the spontaneity of temporary dwelling in the official site's materiality, and of Travellers who know (as they say) what they are 'not allowed' to do. The 'irreducible asymmetry' (Žižek 2006: 29), or parallax of the site corresponds to its official, transcendental status as an unhouse, which, like the gypsy defined as a nomad in all possible worlds, fulfils a 'formal-structural function beyond the opposition of the noumenal and the phenomenal' (Žižek 2006: 23). 
The Travellers recognize the complexity of their official identification with the site. They willingly elicit the 'appearance of a boundary' that 'generates resources of power' (Mitchell 1991: 90) between the real house and the site in the space of gesture, between perspective and performance, between-blocks and underground. The Traveller site understood as a parallax is thus a gap in the symbolic order of the house, an unhouse, 'with no ontological consistency of its own' (Žižek 2006: 390). In gestures towards invisible mortar, absent footings, and spontaneous disappearance, the residents enact the fictive conciliation between themselves and the council, the appearance of an agreement that the site remains only because it is permanently on the verge of expulsion.

The more seemingly permanent the temporary becomes, the more elaborate this sphere of gesture needs to be, as the site teeters between excess and absence of something that would make it what it must not be, either an agent endowed with its own point of view, or a mere simulation. To understand the something that is at stake, we must look more closely at the timing and context of this particular raid.

\section{Sites as homes}

In 2004, in the case of Connors $v$ the United Kingdom (ECtHR 2004, App. No. 66746/01), the UK government argued in the European Court that the legal status of Traveller siteswhere Travellers had rights of tenure comparable neither to housed local authority tenants nor to residents of private residential caravan sites-was a way of protecting nomadism. The UK argued that such rights were against the interests of nomads. ${ }^{12}$ By this account, turning people out onto the side of the road (where their presence was, in any case, illegal,) was merely restoring nomads to their proper way of life. Finding against the state, the Strasbourg court perceptively described the UK's Traveller population as "nomadic in spirit but not in actual or constant practice' (ECtHR Judgment 2004, App. No. 66746/01: 29). The judgment pointed towards the increasing complexity and tenuous legality of what had become, in effect, the architectural condition of permanent temporariness.

The raid described above formed part of a wider post-Connors backlash. As soon as the officials left the site, the residents made phone calls and discovered that identical raids had been carried out on all councilowned sites across the county. Evidently, the aim was to reduce the minimal security of long-term Traveller communities before legal reforms that must inevitably follow Connors brought Travellers closer to the status of council house tenants or protected site residents. Before they left the site, the officials' final act was to issue each family (by yard) an Acceptable Behaviour Contract (ABC). ${ }^{13}$ Everyone was told that unless they signed these so-called agreements they would be evicted. Far from being a tenancy agreement, an $A B C$ paves the way for a local authority to seek an Anti-Social Behaviour Order (ASBO), or banning order, constituting a quick and easy method of barely legal eviction.

What was it about the Connors judgment that inspired this reaction? The impact of Connors stemmed from the finding that sites were 'homes' under Article Eight of the European Convention on Human Rights. We should consider what is at stake in the undefined concept of 'home' (Fox 2005). Home, attached to but mystically distinct from the house, gathers the 'structures of feeling' (Williams 1977: 132) of a twentieth century Euro-American habitus into the conviction that our homes are works of individuation, reflections of intimacy, and expressions of autonomy and desire. Home configures the ideology of a domain of subjectivity untouched by the historical structures of power of a public domain that exists somewhere else, but not here. Home, as noted above, resists an unresolved tension between property and the public status of private life, jointly objectified in the house. In other words, homes are the generative sites of subjects constituted by a particular political-economic form of the 
house, which was now radically challenged by Connors.

In finding that sites, yards, caravans and chalets were homes, the European Court, in the idiom of human rights law, introduced the 'gypsy' (sic) as a natural person, invoking the intentionality of dwelling and familism in which Traveller subjects are creative agents. Home, defined under Article Eight as 'the place where someone lives,' encompasses the body's extension into objects, acts, and contingent relations of dwelling so that, exceeding their ordinary materiality, they become referents of personhood. ${ }^{14}$ Postnomadic subjects, described by the court as 'nomadic in spirit, but not in ... practice' (ECtHR Judgment 2004, App. No. 66746/01: 29), brought the fetishised category of the gypsy as nomad under attack. Gypsy dwelling in the curious modality of the permanently temporary site might now be seen as an equal position in the field legitimized by the house, and, in fact, as simply another form of the house.

The implications of the Connors judgment, together with the reforms of the 2004 Housing Act, which ruled that local Travellers' accommodation needs must be assessed together with those of settled residents, were perceived as a comprehensive attack on local government. The Traveller site was visibly merging into the house, and the raids formed part of a bid to re-inscribe its ideological separation.

Reforms ${ }^{15}$ introduced following Connors mean that local authority sites nominally share the same security of tenure as residents of private park homes, and that the caravan as home is also property. Planning Circular 1/06 (ODPM 2006) introduced a modified definition of the nomad, ostensibly in order to reduce instances of old, sick, and vulnerable people being turned out onto the road, because their bid to establish a legal, private site through planning permission could be rejected on the basis that, by this evidence alone, they were no longer legal gypsies. Its effect on evictions and planning approvals has been minimal. Notwithstanding these changes, planning law's definition of nomadic gypsy dwelling, derived from Mills, meaning 'with no, or no fixed, employment and with no fixed abode' (All E.R.100 at 103H, cited in Sandland 1996: 388), remains the essential underpinning of the permanently temporary site. Whatever 'goes below the ground' or between the blocks materialises a diminishing distance from the permanent house that the critical category of the gypsy-a nomad in all possible worlds-is held to justify.

\section{The field of the house}

To conclude, I turn to the problem of subjectivity, and to Bourdieu's account of the dialectic of habitus and field: the relation between the 'embodied dispositions' and 'belief' of habitus (1990: 68-70) and fields of power, practice, and sociality, whose earliest paradigm in Bourdieu's work is that of dwelling and architecture in the Kabyle house (1977). The overarching question is whether post-nomadic subjectivity can be understood as the habitus of the permanently temporary site.

At first sight we have what, in Bourdieu's terms, is a paramount example of a field: that of the post-war house. It is characterised by complicity between unequally positioned agents (landowners, householders, landlords, and tenants), the habitus of home where 'history turned into nature is denied as such' (Bourdieu 1977: 78), and dominated by technical and legal specialists whose 'symbolic power' is veritably the 'power to make things with words' (Bourdieu 1989: 23), and whose ultimate object is control over the magic of commodity. The Traveller site demonstrates the arcane "magic of a world of objects' (Bourdieu 1977: 91) that defines the production of this field. In one area, the symbolic magic of temporariness is policed through the quest for invisible mortar and footings. Elsewhere, another official, indifferent to mortar, insists that a small gap be left between the blocks, so that, when lying flat on the ground, he can see the tiny wheels that enable the chalet to be rolled onto the ramps of a low-loader. Through the arcane 
magic of such techniques, symbolic capital imposes its 'vision of divisions' (Bourdieu 1989: 23) of the social world.

But the difficulty remains that these techniques and the objects that they create are neither exactly inside nor outside the field of capital determined by house-home-property. Moreover, the power of its specialists is visibly diminishing in the face of external agency. They appear to police the insecure boundary of the permanent house while simultaneously creating a space within it for the permanently temporary site. The interdependence and opposition between spheres of value described here as house-home-property provide a clue as to why this is so.

First, the autonomisation of fields that Bourdieu describes never finally or fully results in their autonomy, and fields, such as that of the house, collapse into indeterminacy and contradiction as they exceed, or fall short of, the historical necessities of the distribution of capital. These stumbling blocks suggest the persistent permeability and mutual resistance of fields: that their divisions of labour are incomplete. Following from this, the multiplicity of perspectives of subjects who inevitably inhabit not one, but multiple fields, repeatedly reconstitutes the parallax, or blind spot of minimal difference, in magical objects themselves. Contours of interdependence and resistance that incompletely determine objects in relation to other objects (such as house and home) constitute the resources from which new objects, interpretations, and subjectivities may arise.

The post-war house, whose in-built standards of material substance, dimensions, and permanence seemed so certain and well arranged, is suddenly discovered to contain, or to have invited in, the temporariness it worked so hard to expel. The productive ambiguity of objects is thus the resisted source of the deformation of the sovereignty (Butler 2000) of the house in its encounter with the Traveller site, where post-nomadic unhouses constitute an imminent property market. I take the lesson of the parallax to imply that materiality is neither a form of closure that encompasses an object's entrance into history, nor are human frames of meaning distinct from objects themselves.

\section{The politics of gesture}

As the spectre of a land market for private sites begins to loom-driven since 1994 by Traveller ownership of sites, both legal and illegal-Travellers who seek planning permission for a (new or existing) site are regularly challenged to prove their legal status as gypsies in the form of an aversion to bricks and mortar' (cf. Johnson and Willers 2007: 229-231). Gypsy status, a legal artefact that protects the boundaries of the house, is now made visible, not through the increasingly indefinable 'gypsy way of life, ${ }^{16}$ but as the interiority of the subject as a natural person. Psychiatrists who testify in court to this aversion among $\mathrm{g} /$ Gypsies thus seek to uphold the autonomy of subjects collectively determined by a pathology of architectural self-exclusion. Beyond the opposition of an imagined life on the road, 'which remains the same in all possible (symbolic) universes' (Žižek 1997: 50), to which nomadic gypsies must still affirm their unwavering commitment, and an admission of its unattainability, the planning process-like the raid-elicits the parallax of the real g/Gypsy, whose desires and aversions, with remarkable consistency, confirm the rationality of law itself.

The 'new twist' (Balibar 1994: 13) in this apparent interiorisation of $\mathrm{g} /$ Gypsy status is simply that the claim to private life in the site assumes the public self-relation of a very particular 'transindividual' voice, now openly declaring an 'aversion' to the house in pursuit of the permanently temporary. There is neither parody nor insincerity in this configuration of post-nomadic subjectivity any more than there was in the Travellers' offer during the raid to make the site disappear. But, in view of what we have argued concerning the inadequacies of Bourdieu's idealised dialectic between habitus and field, we can scarcely understand post-nomadic subjectivities as 
the embodied dispositions of habitus. To understand how post-nomadic architecture's public-private subjectivity is made visible, we might draw on Agamben's concept of gesture as the process of making means visible as such' (Agamben 2000: 56-7). Gesture marks the intersection between what would negate or cancel each other out, such as spontaneity and performance, life and art, or public and private. It is the point at which conflict and accommodation meet and separate, still unresolved. Agamben writes:

The gesture is neither use value nor exchange value, neither biographic experience nor impersonal event: it is the other side of the commodity that lets the 'crystals of this common social substance' sink into the situation. (Agamben 2000: 80)

The social and material relations of permanent, temporary dwelling, affirmed in gestures of desire and aversion by post-nomadic subjects, communicate the uncertain limits and possibilities of a social and material world whose sphere of mediality is architecture, where ethical commitments and political economy intersect.

\section{Acknowledgements}

The author expresses thanks to the Arts and Humanities Research Council for the funding that enabled this doctoral research to be carried out, and to the Institute of Irish Studies for a grant to assist thesis writing. Thanks are also due to the anonymous reviewers and editors for their constructive comments and assistance in the course of preparing this article.

\section{Notes}

${ }^{1}$ Aufhebung or sublation in Hegelian dialectic refers to the interagency of thesis and antithesis that subsumes their opposition.

${ }^{2}$ Article Eight, European Convention on Human Rights affords protection to "private and family life ... home and ... correspondence'.
${ }^{3}$ Irish Travellers and English Romanies are both regarded as ethnic Gypsies in UK law.

${ }^{4}$ For example, Planning Circular 1/06 (ODPM 2006).

${ }^{5}$ Until 1965, building standards were established by local bylaws by councils or set out in non-statutory guidelines. The Public Health Act 1961 laid the ground for statutory national building standards that followed in the Building Regulations 1965.

6 'Officialization is the process whereby the group (or those who dominate it) ... binds itself by a public profession which sanctions and imposes what it utters, tacitly defining the limits of the thinkable and the unthinkable' (Bourdieu 1990: 108).

7 Following the Criminal Justice and Public Order Act (1994), which abolished the duty of local authorities to provide site for 'gipsies,' Planning Circular 1/94 envisaged that Travellers would seek to acquire land of their own for sites and set out guidance and restrictions. (See Kenrick and Clark 1999: 141-144).

${ }^{8}$ Although the Act also extended to hawkers and itinerant traders, Sandland notes, 'the offence did not turn on status but on actively hawking or trading' (Sandland 1996: 401, n. 49).

${ }^{9}$ See $R$ (Margaret Price) $v$ Carmarthenshire County Council. [2003] EWHC 42 (Admin), Legal Action March 2003 pp. 30-31.

${ }^{10}$ This account is drawn from my doctoral fieldwork carried out between 20062008 in the UK and Ireland.

11 Žižek describes the phenomenon of parallax, drawn from astronomical observation, as "the apparent displacement of an object (the shift of its position against a background), caused by a change in observational position' (2009: 17).

${ }^{12}$ This argument had been accepted by UK courts in the earlier cases of Somerset County Council v Isaacs (2002) EWHC 1014 (Admin), and $R$ (Albert Smith) $v$ LB of Barking and Dagenham (2003) EWCA Civ. 385; EWCH 2400 Admin. 
13 See: Home Office (2006): A Guide to Anti-Social Behaviour Orders and Acceptable Behaviour Contracts. http:// webarchive.nationalarchives.gov. uk/20100413151441/http:/crimereduction.homeoffice.gov.uk/asbos/asbos9.pdf

${ }^{14}$ Article Eight 'concerns rights of central importance to the individual's identity, self-determination, physical and moral integrity, maintenance of relationships with others and a settled and secure place in the community' (ECtHR Judgment 2004, Connors v. The United Kingdom App. No. 66746/01: 24).

15 The Housing and Regeneration Act 2008 extended the provisions of the Mobile Homes Act 1983 to local authority site residents.

16 '[T]here is a positive obligation imposed on the Contracting States by virtue of Article 8 to facilitate the gypsy way of life' Chapman v United Kingdom (2001) 33 EHRR 399 at para 96.

\section{References}

Abercrombie, P 1945 Greater London Plan 1944. London: HMSO.

Adams, B, Okely, J, Morgan, D and Smith, D 1975 Gypsies and Government Policy in England. London: Heinemann Educational Books Ltd.

Agamben, G 2000 Means Without End: Notes on Politics. Minneapolis: University of Minnesota Press.

Agamben, G 2005 State of Exception. Translated by Attell, K. Chicago: University of Chicago Press.

Balibar, E 1994 Subjection and Subjectivation. In: Copjec, J (ed.) Supposing the Subject. London: Verso.

Bourdieu, P 1977 Outline of a Theory of Practice. Cambridge: Cambridge University Press. DOI: http://dx.doi.org/10.1017/ CBO9780511812507

Bourdieu, P 1985 The Genesis of the Concepts of Habitus and of Field. Sociocriticism 1(2): pp. 11-24.
Bourdieu, P 1989 Social Space and Symbolic Power. Sociological Theory 7(1): pp. 14-25. DOI: http://dx.doi.org/10.2307/ 202060

Bourdieu, P 1990 The Logic of Practice. Cambridge: Polity Press.

Butler, J 2000 Antigone's Claim: Kinship Between Life and Death. New York: Columbia University Press.

Department for Communities and Local Government 2008 Implementing the Mobile Homes Act 1983 on local author ity Gypsy and Traveller Sites: Consultation. Wetherby: CLG Publications.

Dodds, N 1966 Gypsies, Didkois and Other Travellers. London: Johnson Publications.

Engels, F 1948 [1891] The Origin of the Family, Private Property and the State. Moscow: Progress Publishers.

Evans, S 2004 Stopping Places. Hatfield: University of Hertfordshire Press.

Feldman, A 2001 Philoctetes Revisited: White Public Space and the Political Geography of Public Safety. Social Text 68(vol. 19, no. 3): pp. 57-90.

Foucault, M 1980 Power/Knowledge: Selected Interviews and Other Writings 1972-1977. New York: Pantheon Books.

Fox, L 2005 The Idea of Home in Law. Home Cultures 2(1): pp. 25-50. DOI: http:// dx.doi.org/10.2307/202060

Fraser, A 1993 The Gypsies. Oxford: Blackwell.

Home Office 2006 A Guide to Antisocial Behaviour Orders. http:// webarchive.nationalarchives.gov.uk/ 20100405140447/http:/asb.homeoffice. gov.uk

Jackson, P 1965 The Law and the Caravan. The Modern Law Review 28(2): pp. 216220. DOI: http://dx.doi.org/10.1111/ j.1468-2230.1965.tb01060.x

Johnson, M and Willers, M 2007 Gypsy and Traveller Law. 2nd ed. London: Legal Action Group.

Kenrick, D and Clark, C 1999 Moving On. Hatfield: University of Hertfordshire Press. 
Mann, M 1961 Caravan Sites and Control of Development Act, 1960. The Modern Law Review 24(1): pp. 150-155.

Mayall, D 1988 Gypsy-Travellers in Nineteenth-Century Society. Cambridge: Cambridge University Press.

Ministry of Housing 1959 Caravans as Homes. Cmnd 872. London: HMSO. (Wilson Report)

Mitchell, T 1991 The Limits of the State: Beyond Statist Approaches and Their Critics. The American Political Science Review 85(1): pp. 77-96. DOI: http://dx.doi. org/10.2307/1962879

Neuman, G 1996 Anomalous Zones. Stanford Law Review 48(5): pp. 1197-1234. DOI: http://dx.doi.org/10.2307/1229384

Sandland, R 1996 The Real, the Simulacrum, and the Construction of the 'Gypsy' in Law. Journal of Law and Society 23(3): pp. 383-405. DOI: http://dx.doi. org/10.2307/1410718

Stolcke, V 1995. New Boundaries, New Rhetorics of Exclusion in Europe. Current Anthropology 36(1): pp. 1-24. DOI: http://dx.doi.org/10.1086/204339

Vesey-Fitzgerald, B 1944 Gypsies of Britain. London: Chapman and Hall.

Warner, M 2002 Public and Private. In: Publics and Counterpublics. New York: Zone Books, pp. 65-124.

Willems, W 1998 Ethnicity as a Death-Trap: the History of Gypsy Studies. In: Lucassen, L, Willems, W, and Cottaar, A-M Gypsies and Other Itinerant Groups: A Socio-Historical Approach. Basingstoke: Palgrave, pp. 17-34.

Williams, R 1977 Marxism and Literature. Oxford: Oxford University Press.

Yiftachel, 02009 Critical Theory and 'Gray Space:' Mobilisation of the Colonized. City
13(2): pp. 246-263. DOI: http://dx.doi. org/10.1080/13604810902982227

Žižek, S 1997 The Plague of Fantasies. London: Verso.

Žižek, S 2006 The Parallax View. Cambridge MA: The MIT Press.

\section{Statutes and Legal Cases}

Caravan Sites Act 1968 C. 52. London: HMSO.

Caravan Sites and Control of Development Act 1960 C. 62. London: HMSO.

Chapman v United Kingdom (2001) 33 EHRR 399.

Connors v United Kingdom (2005) 40 EHRR 9.

Criminal Justice and Public Order Act 1994 C. 33. London: HMSO

ECtHR Press Release by the Registrar, Connors $v$ United Kingdom (2004) App No. 66746/01.

Highways Act 1959 C. 25. London: HMSO.

Housing Act 2004 C. 34. London: HMSO.

Housing and Regeneration Act 2008 C. 17. London: HMSO.

Mills v Cooper (1967) All ER 100.

Mobile Homes Act 1983 C. 34. London: HMSO.

Office of the Deputy Prime Minister 2006 Circular 01/2006. Planning for Gypsy and Traveller Caravan Sites. London: HMSO.

Public Health Act 1961 C. 64. London: HMSO. $R$ (on the application of Albert Smith) v Barking and Dagenham London Borough Council (2003) EWCA Civ 385; EWCH 2400 Admin.

$R$ (on the application of Margaret Price) $v$ Camarthenshire County Council (2003) EWHC 42 Admin; March 2003 Legal Action 30, QBD (Admin Ct).

Somerset County Council v Isaacs (2002) EWHC 1014 (Admin Ct).

The Building (First Amendment) Regulations1965. S.I. No. 2184. London: HMSO. 
How to cite this article: Hoare, A E 2014 The View from the Traveller Site: Post-nomadic Subjects and the Material Relations of Permanent Temporary Dwelling. Opticon1826, (16): 18, pp.1-16, DOl: http://dx.doi.org/10.5334/opt.bz

Published: 15 October 2014

Copyright: ( 2014 The Author(s). This is an open-access article distributed under the terms of the Creative Commons Attribution 3.0 Unported License (CC-BY 3.0), which permits unrestricted use, distribution, and reproduction in any medium, provided the original author and source are credited. See http://creativecommons.org/licenses/by/3.0/. ] $\mathrm{u}\left[\begin{array}{c}\text { Opticon1826 is a peer-reviewed open access journal published by } \\ \text { Ubiquity Press }\end{array}\right.$ 